\title{
From Ill-Defined Extracts to the Immunomodulatory Lectin: Will There be a Reason for Oncological Application of Mistletoe?*
}

\author{
Hans-J. Gabius ${ }^{1,4}$, Sigrun Gabius ${ }^{1}$, Shantaram S. Joshi ${ }^{2}$, Bernhard Koch ${ }^{3}$, Michael Schroeder $^{3}$, \\ Walter M. Manzke ${ }^{3}$, and Martin Westerhausen ${ }^{3}$ \\ ${ }^{1}$ Institut für Physiologische Chemie, Ludwig-Maximilians-Universität, Veterinärstr. 13, D-80539 München, \\ Federal Republic of Germany \\ ${ }^{2}$ Department of Cell Biology and Anatomy, University of Nebraska Medical Center, 600 South 42nd Str., Omaha, \\ NE 68198-6395, U.S.A. \\ ${ }^{3}$ Medizinische Klinik II, St. Johannes Hospital, An der Abtei 7-11, D-47166 Duisburg, Federal Republic of Germany \\ ${ }^{4}$ Address for correspondence
}

Received: March 2, 1993; Revision accepted: April 2, 1993

\section{Introduction}

Promotion for supposed remedies of cancer obeys the laws of the market like similar activities in any other segment within the distribution of pharmaceuticals. It is thus not surprising that non-conventional methods with unproven efficacy are deliberately and suggestively favorably referred to as alternative methods (1). Since half to two thirds of the tumor patients actually apply such methods, the discrepancy between the commercial suc-

\footnotetext{
* Dedicated to Prof. Dr. F. Cramer on the occasion of his 70th birthday.
}

with advanced cancer no at least partial remission was seen. In principle, enhancement of factors like cytokine availability or NK-cell activity is not necessarily linked to therapeutic benefit. Factors such as growth promotion of certain tumor cell lines by cytokines, occurrence of respective insensitivity in advanced stages or varying levels of target sensitivity to cell-mediated cytotoxicity with significant interindividual differences deserve attention. Each tumor class has to be considered separately for its responsiveness. Similarly crucial for the decision of the focus of trials are valid suggestions for indicators to reliably recognize responders. Monitoring, for example, the presence of cytokine receptors or of MHC epitopes on tumor cells or the stimulation of the levels of acute-phase proteins in serum may be helpful. Taken together, this generally applicable course of research for a rigorously defined plant preparation or an isolated compound, culminating in the decisive clinical trials according to the approved criteria, will help answer the pertinent question on the oncological relevance of this treatment modality.

\section{Key words}

Lectin, Viscum album, cancer, therapy, cytokines, immunomodulation. cess/subjective attitude of the customer/patient and the scientific judgment on the basis of the accessible data is obvious $(1-5)$. Taken as an example, rigorous analysis of the published clinical reports on the application of commercial mistletoe extracts has led to the conclusion that their uncontrolled routine application is not justified $(6,7)$. In line with this conclusion, no antitumoral effect on autochthonous tumor models was noted with a commercial preparation (8). Prompted by the prevailing popularity of this type of extract, our review illustrates the indispensable steps that have to be taken to finally and unmistakably answer the pertinent question in clinical trials, whether any measurable benefit may be expected in oncological application. 


\section{The Extract: A Complex Mixture with Varying Composition}

The application of mistletoe extracts in oncology is mainly rooted in Steiner's world of ideas (9). Overall, seven different types of extract are at present commercially available (7). Considering the presence of diverse classes of distinct constituents and the different modes of extract preparation $(7,10-12)$, it requires little persuasion to accept the argument that presentation of unequivocal proof for effective substance(s) and the required dose(s) as well as the adequate standardization of the various products is imperative. It should also not be overlooked that allergic reactions in response to extract application can occur, demanding precise definition of the responsible compounds and concentrations (13). Drastic variations in the concentration of one compound between different product batches emphasize the necessity for rigorous product standardization $(14,15)$.

\section{The Lectinological Approach}

Recent research on mistletoe compounds has focussed on the major lectin. It is guided conceptually by the observations that mammalian lectins (carbohydrate-binding proteins that are distinguishable from antibodies and enzymes) are involved in immunoregulation, cell adhesion, and tumor progression (16-19). The galactoside-specific lectin, termed Viscum album agglutinin (VAA), mistletoe lectin-I (ML-I), or viscumin, has been initially purified by three groups (20-22). It consists of two types of chains, linked by a disulfide bond. The B-chain confers the lectin activity to the dimer, whereas the Achain acts as an RNA $N$-glycosidase on $28 \mathrm{~S}$ rRNA, causing the toxicity of the hololectin (23). Further biochemical studies revealed that two different A-chains are present $(24,25)$. Their $N$-terminal sequences indicate a high level of relationship and argue against artefactual origin by proteolysis due to the evolutionary neutral amino acid substitutions (25). Interestingly, genes for two distinct A chains have been detected in the case of the related toxin abrin of Abrus precatorius (26). To reach a definite conclusion on this issue, similar cloning of mistletoe genes is required, as already performed for other toxic mistletoe proteins, e.g. viscotoxins (27).

Both types of subunit are glycosylated with oligomannose-type glycans and a common core element of many plant glycoproteins, namely a mannotriosyl $\rightarrow N, N^{\prime}$ diacetylchitobiose glycan containing a xylosyl and an $\alpha$ fucosyl group $(20,28)$. To circumvent the problem that access to the purified lectin may become a limiting factor for ensuing research, its purification was optimized by systematically assessing the yield in correlation to ligand linkage and type of spacer within affinity chromatography (24). Processing of $12 \mathrm{~g}$ dried mistletoe that is commercially available (Herba Visci albi: $1 \mathrm{~kg}$ costs about \$ 7) will result in approximately $1 \mathrm{mg}$ lectin, seasonal and annual variations influencing the yield.

It is quite common for plant lectins and toxins to be separable into variants according to their $\mathrm{pI}$ (29). Further two-dimensional gel electrophoretic analysis of VAA, too, has revealed heterogeneity on the level of each subunit $(30,31)$. As already noted, detailed sequence analysis is called for to answer the question as to whether isolectins are actually encoded on the genomic level or whether this heterogeneity originates during tissue processing.

In order to proceed to the problem of the clinical relevance of the lectin, cloning is not indispensable due to the easy access of large quantities of the lectin by routine extract fractionation. The purified material serves several purposes. It enables establishment of a sensitive quantitation assay, combining the specific, carbohydratedependent binding of active lectin with the high sensitivity of the ELISA-technique (32). This assay reliably determines ng-quantities of the galactoside-binding lectin (18). Similarly, by employing a high-affinity glycoligand, namely asialofetuin, the sugar specificity can be elucidated. The extent of oligosaccharide-mediated inhibition of attachment of the lectin to the glycoligand uncovers its specificity. The lectin binds to terminal galactose residues, has no preference for the anomeric linkage, most importantly recognizes the axial $4^{\prime}-\mathrm{OH}$ of galactose, and exhibits a relatively high affinity for clustered ligands (33). Since galabiose is among the inhibitors of VAA-dependent haemagglutination (34), we have already ascertained that globotriaosyl ceramide is a potential ligand for the lectin (unpublished observation).

Since the lectin can be labelled via its accessible amino groups without harmful impact on its activity $(25,33)$, binding to cellular ligands can be followed not only on the level of model glycoligands or individual glycoconjugates. Cell binding studies, too, are feasible. A population of $10^{6}$ mouse spleen cells, for example, contains $79 \%$ positive cells, when incubated with $5 \mu \mathrm{g}$ lectin $/ 100 \mu \mathrm{l}$ (Fig. 1). Binding studies with human cells discerned positive cooperativity at low concentrations of lectin (25). The Hill coefficient of this binding mode is approximately 1.5 (Fig. 2). Positive cooperativity of binding of lectins has been linked to elicitation of cellular responses and growth regulation (35-38). Interestingly, this range of VAA concentration is effective to trigger intracellular biosignalling, as exemplarily documented for the increase of intracellular avallability of $\mathrm{Ca}^{2+}$ ions (Fig.3). Lectin-dependent enhancements of increased protein phosphorylation and production of phosphatidylinositol 4,5-bisphosphate have also been substantiated $(25,39)$. Of potential importance in the clinical context is the observation that enhanced secretion of interleukin-1, interleukin-6, and tumor necrosis factor- $\alpha$ belongs to the responses to lectin treatment (40). Control studies in the presence of inhibitory sugar confirm that galactose-specific binding is essential for this response (25, 40). In vitro measurements thus point to the importance of rather low doses of lectin to affect cellular parameters, namely nanogram quantities per assay. It should be added at this point that it is not at all justified to claim correlations between an immunomodulatory activity and in vivo therapeutic effects already at this stage, as recently done (41), and that even smaller quantities of lectin, namely picograms per $\mathrm{ml}$, had been indicated to effectively decrease a parameter of unknown physiological relevance, the negative net charge of guinea pig macrophages (42). 


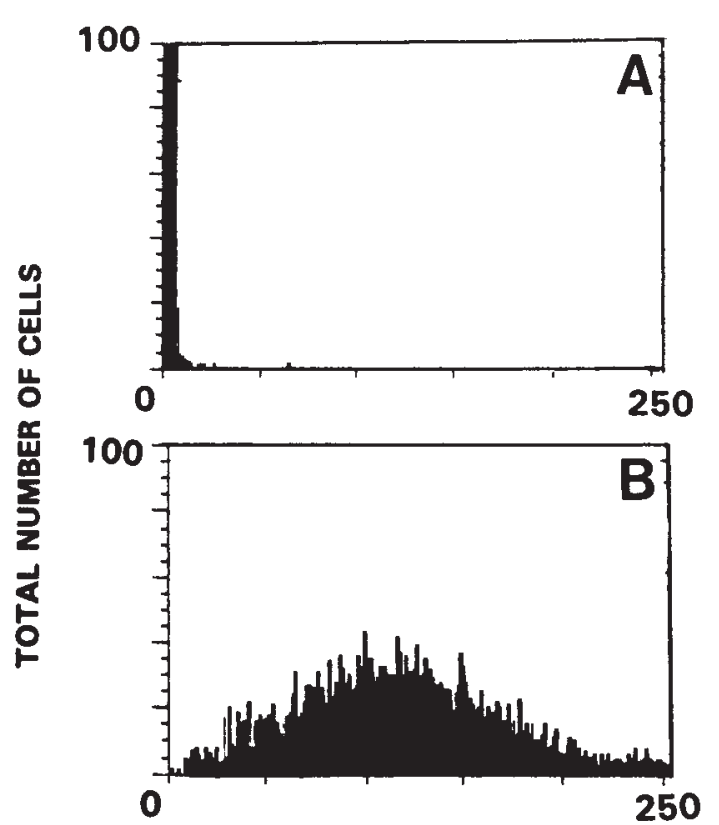

GREEN FLUORESCENCE

Fig. 1 Flow cytometric analysis of normal Balb/c splenocytes, treated with biotinylated mistletoe lectin (VAA). One million splenocytes were incubated with $5 \mu \mathrm{g}$ of VAA in a total volume of $100 \mu$ for one hour on ice. The cells were then washed three times with phosphate-buffered saline containing $2 \%$ fetal calf serum, followed by incubation with avidin-FTC for 30 minutes on ice. The cells were washed 3 times to remove the fluorescent marker and the percentage of positive cells was determined using an Ortho $50 \mathrm{H}$ flow cytometer. Control background staining with avidin-FTC (A) and the extent of specific labelling of VAA-treated cells $(B)$ are shown.

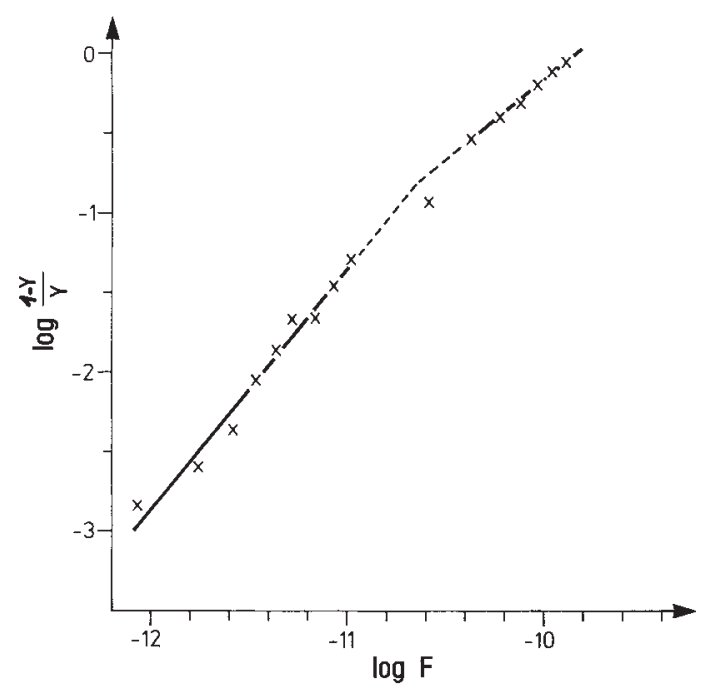

Fig. 2 Hill plot analysis of data for specific binding of the lectin to human monocytic leukemia cells (THP- 1$)$ at $4{ }^{\circ} \mathrm{C}\left(5 \times 10^{5}\right.$ cells/assay), revealing a coefficient of 1.49 that is indicative for positive cooperativity at low lectin concentration.

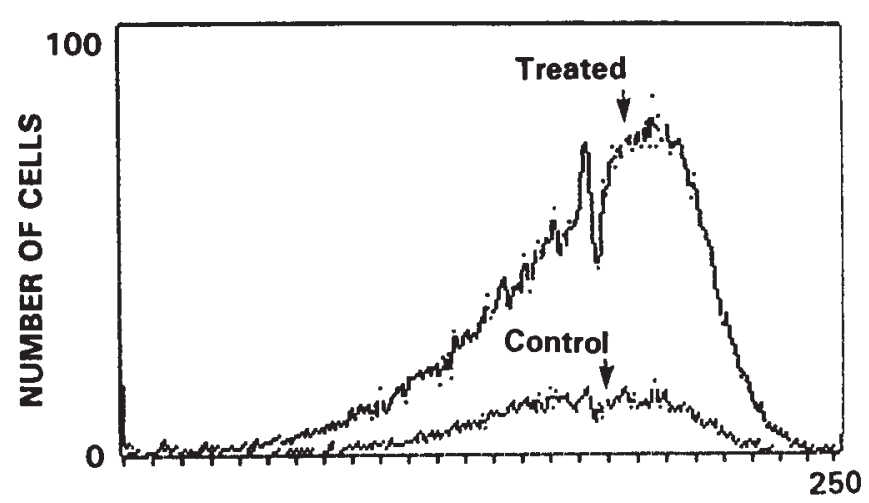

RELATIVE GREEN FLUORESCENCE

Fig. 3 Flow cytometric analysis of murine macrophage/monocyte J774A.1 cells with respect to the intracellular $\mathrm{Ca}^{2+}$-concentration in response to exposure to VAA. The cells were loaded with the indicator dye Fluo-3/AM and then incubated in the absence (control) or presence of $10 \mathrm{ng} / \mathrm{ml} \mathrm{VAA}$ (treated).

\section{The Lectin as Biological Response Modifier}

The in vitro measurements warranted the turn of attention to the examination of effects of low doses of lectin in vivo. This part of the studies is aimed at the establishment of a solid foundation for subsequent clinical trials, if a continuation of the research is supported by the experimental evidence.

Increases of the weight of the thymus had been reported after injections of $0.1-1 \mu \mathrm{g} / \mathrm{day} \times \mathrm{kg}$ of a protein preparation from mistletoe extract into mice and rats, its high lability precluding comprehensive studies (43). Nanogram quantities of purified lectin per $\mathrm{kg}$ body weight, given s.c. or i.p., caused significant increases in this parameter $(44,45)$. However, the lectin is characterized by a high degree of stability in contrast to the described protein preparation.

Besides the weight of the thymus several other parameters have been monitored. Variations of the injected quantities ascertained an optimal dose range of $0.7-2 \mathrm{ng}$ lectin $/ \mathrm{kg}$ at biweekly s.c. injections for humans, mice, and rabbits, when alterations in the number of large granular lymphocytes were considered as an index for immunomodulation $(46,47)$. The number of NK cells and their cytotoxicity to lymphoma targets significantly increased in treated mice (Fig. 4). Notably, the immunomodulatory potency of extracts, applied in this dose range with respect to the lectin and measured in terms of body temperature increase, number and activity of polymorphonuclear leukocytes and large granular lymphocytes, was abolished by chromatographic removal of the lectin (46). Similarity of the extent of triggered effects by injection of identical doses of lectin in extracts for patients and volunteers as well as of purified lectin for animals is a further line of evidence that the lectin, not a complex mixture of substances, is effective to cause modulation of immunological parameters $(46,47)$. These results on the conspicuous activity of the lectin notwithstanding, the re- 


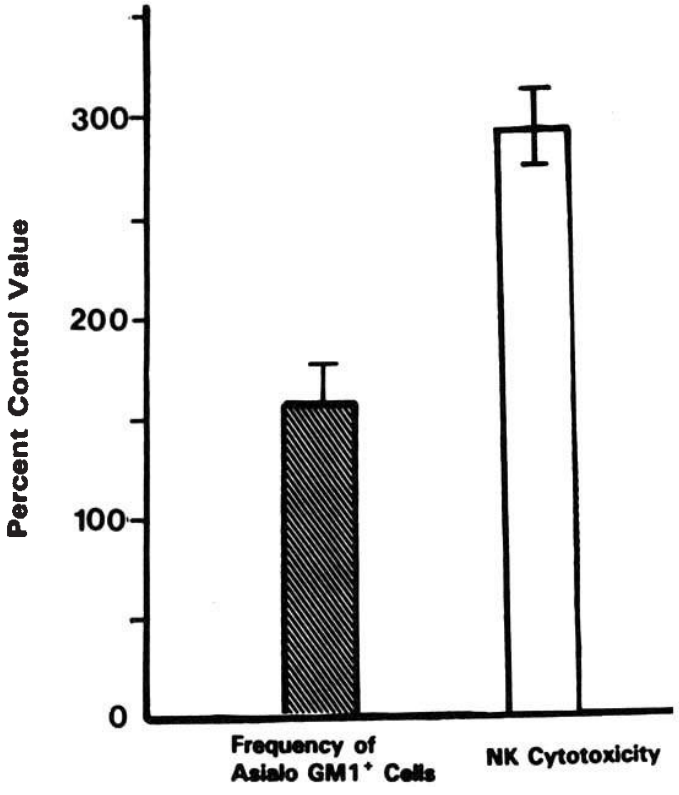

Fig. 4 Frequencies of asialo-GM $M_{1}$ positive cells (natural killer cells) from spleens of mice, treated with VAA, and of control mice. Splenocytes from VAA-treated and control mice were incubated with rabbit polyclonal antibodies to asialo-GM $\mathrm{GM}_{1}$, followed by FTC-labelled goat anti-rabbit antibodies. The percentage of positive cells was determined by flow cytometry. The results are expressed as percentage of the control value on the basis of three independent experiments. Cytotoxicity of spleen cells against murine YAC-1 lymphoma cells from control mice and from VAA-treated mice was determined by in vitro cytotoxicity assays. The results are expressed as the percentage of the control value at an effector : tumor cell ratio of $100: 1$. The value represents the mean of 3 independent experiments.

ported enhancement of cytotoxicity by a dialyzable oligosaccharide fraction from certain extract preparations should also be pursued in vivo in tumor models to prove any measureable benefit $(48,49)$.

Lectin-dependent effects in breast cancer patients furthermore include increases of the number of helper T cells and CD25-positive cells in addition to NK cells and of the concentrations of tumor necrosis factor- $\alpha$ and interleukin- 6 in serum, consequently of the levels of acute-phase proteins like CRP, individual differences between various patients being manifest $(40,50,51)$. As already emphasized and substantiated by ample clinical experience with diverse biological response modifiers, such changes in some parameters, taken from the complexity of the immune system without precise knowledge about the actually crucial indicators for the desired antitumoral response, do not necessarily translate into an effective treatment. The next step thus leads to animal tumor models.

The inherent problems to draw clinically relevant conclusions from changes in various parameters and from experience with animal tumor model systems notwithstanding, these model studies can at least indicate whether or not tumor growth and spread will be affected in a model by a regimen that causes immunomodulation. Indeed, antimetastatic/antitumoral effects of the lectin treatment were seen for a lymphosarcoma (RAW117), a fibrosarcoma (L-1), and a melanoma (B16) model system $(44,45$; Vidal-Vanaclocha et al., in preparation). Remarkably, reduction in the number of metastases and the tumor growth, accompanied by prolonged survival but not by a curative effect, was consistently determined. Having elucidated the schedule and dose of application that results in modulation of immune parameters in animals, volunteers and patients as well as in antimetastatic/antitumoral responses in three animal models, clinical trials according to standard designs can now be deliberately planned to thoroughly assess any oncological effect of this treatment suggestion. Controlled biweekly s.c. injections of a dose of $1 \mathrm{ng}$ lectin/ $\mathrm{kg}$ body weight have already been performed on a limited number of patients who did not respond to chemotherapy or refused continuation of this regimen (Table 1) or who received this modality as second or third line treatment in conjunction with chemotherapy or radiation (Table 2). No partial or complete remission nor

Table 1 Clinical details of patients, treated with VAA

\begin{tabular}{|c|c|c|c|c|c|c|c|c|}
\hline \multirow{2}{*}{ Patient } & \multirow{2}{*}{ Sex } & \multirow{2}{*}{$\begin{array}{l}\text { Tumor } \\
\text { type }\end{array}$} & \multirow{2}{*}{ Metastases } & \multicolumn{2}{|c|}{ Periods } & \multirow{2}{*}{$\begin{array}{l}\text { Survival } \\
\text { time }\end{array}$} & \multirow{2}{*}{\multicolumn{2}{|c|}{$\begin{array}{c}\text { Status } \\
\text { prior after } \\
\text { treatment }\end{array}$}} \\
\hline & & & & A & $B$ & & & \\
\hline 1 & $\mathrm{~m}$ & BC-SC & - & 12 & 12 & 12 & $\mathrm{NC}$ & PD \\
\hline 2 & $\mathrm{~m}$ & BC-SC & - & 7 & 3 & 3 & PD & PD \\
\hline 3 & $f$ & BC-NSC & - & 6 & 3 & $12+$ & PD & PD \\
\hline 4 & $\mathrm{~m}$ & BC-NSC & + & 22 & 3 & 4 & PD & PD \\
\hline 5 & $f$ & CRC & + & 75 & 15 & 22 & PD & PD \\
\hline 6 & $\mathrm{~m}$ & CRC & + & 15 & 4 & 8 & PD & PD \\
\hline 7 & $f$ & CRC & + & 13 & 4 & 4 & PD & PD \\
\hline 8 & $f$ & CRC & + & 1 & 13 & 13 & $\mathrm{PD}$ & PD \\
\hline 9 & $f$ & CRC & + & 2 & 24 & $24+$ & $\mathrm{NC}$ & NC \\
\hline
\end{tabular}

Each period is given in months; BC-SC: small cell bronchial carcinoma; BC-NSC: nonsmall cell bronchial carcinoma; $C R C$ : colorectal carcinoma; $A$ : period between date of diagnosis and beginning of lectin treatment; $B$ : period of lectin treatment; survival time is given from the beginning of lectin treatment, + indicating that the patient has been alive at the time of data collection; NC: no change, PD: progressive aisease.

Table 2 Clinical details of patients, treated with VAA in conjunction with chemotherapy or radiation therapy.

\begin{tabular}{|c|c|c|c|c|c|c|c|c|}
\hline \multirow[t]{2}{*}{ Patient } & \multirow[t]{2}{*}{ Sex } & \multirow[t]{2}{*}{$\begin{array}{l}\text { Tumor } \\
\text { type }\end{array}$} & \multirow[t]{2}{*}{ Metastases } & \multicolumn{2}{|c|}{ Periods } & \multirow[t]{2}{*}{$\begin{array}{c}\text { Survival } \\
\text { time }\end{array}$} & \multirow{2}{*}{\multicolumn{2}{|c|}{$\begin{array}{l}\text { Status } \\
\text { prior after } \\
\text { treatment }\end{array}$}} \\
\hline & & & & A & B & & & \\
\hline 10 & $\mathrm{~m}$ & BC-SC & - & 7 & 23 & $23+$ & $\mathrm{NC}$ & PD \\
\hline 11 & $f$ & BC-SC & + & 4 & 5 & 5 & PD & PD \\
\hline 12 & $\mathrm{~m}$ & BC-NSC & + & 10 & 6 & 6 & PD & PD \\
\hline 13 & $f$ & $\mathrm{GC}$ & + & 36 & 3 & 8 & PD & PD \\
\hline 14 & $f$ & CRC & + & 25 & 6 & 9 & PD & PD \\
\hline 15 & $\mathrm{~m}$ & CRC & + & 36 & 13 & 13 & PD & PD \\
\hline 16 & $\mathrm{~m}$ & CRC & + & 17 & 2 & 3 & PD & PD \\
\hline 17 & $f$ & CRC & + & 64 & 2 & 9 & PD & PD \\
\hline 18 & $f$ & CRC & + & 15 & 19 & 19 & $\mathrm{PD}$ & PD \\
\hline 19 & $f$ & CRC & + & 27 & 16 & $16+$ & PD & PD \\
\hline 20 & $f$ & PAC & + & 4 & 8 & 10 & PD & PD \\
\hline 21 & $\mathrm{~m}$ & PRC & + & 21 & 3 & 6 & PD & PD \\
\hline 22 & $\mathrm{~m}$ & UC & + & 51 & 6 & 6 & PD & PD \\
\hline 23 & $f$ & $\mathrm{BDC}$ & + & 24 & 4 & 13 & PD & PD \\
\hline
\end{tabular}

Each period is given in months; BC-SC: small cell bronchial carcinoma; BC-NSC: nonsmall cell bronchial carcinoma; GC: gastric carcinoma; CRC: colorectal carcinoma; PAC: pancreatic carcinoma; PRC: prostatic carcinoma; UC: bladder carcinoma; BDC: carcinoma of the bile duct; $A$ : period between date of diagnosis and beginning of lectin treatment; $B$ : period of lectin treatment; survival time is given from the beginning of lectin treatment, + indicating that the patient has been alive at the time of data collection; NC: no change, PD: progressive disease. 
an impact on relevant tumor markers was seen in this group of patients with advanced cancer, which is a rather unfavorable selection. However, neither were any significant side-effects nor allergic reactions observed. A salient feature in this heterogeneous group is that the acceptance was remarkably high, 15 from the 23 patients claiming a subjective improvement in the quality of life.

On the whole, the evaluation of the properties of the galactoside-specific lectin from mistletoe has passed essential stages that are likewise relevant for any other plant substance with putative clinical importance. Biochemical and cell biological characteristics of the lectin have been described. Among the cellular responses measured, the enhanced secretion of cytokines deserves attention. Modulation of certain immune parameters has occurred in the limited in vivo trials with fixed schedule and dose, albeit with interindividual differences. Mice, which intravenously received highly malignant cells of three model systems, responded to lectin treatment with reduced tumor growth and reduced extent of metastasis formation. The toxicity of the lectin, which is unspecific like that of viscotoxins, does not appear to play a prominent role in this process, because the given dose is orders of magnitude below the toxic range. It is doubtful that this activity can be taken advantage of. A respective study with ricin and the dose-dependent appearance of antibodies argue against such considerations $(52-54)$. To reliably quantitate the concentration of lectin in solutions with appropriate sensitivity, a common lectinological assay system has been adopted. Since patients turn to commercial preparations with unproven efficiency in the hope to augment the performance of effector mechanisms of their immune system $(3,4)$, any uncertainty about the concentration of the potent substance(s) and the constancy of this parameter inevitably leads to serious doubts about the product quality. Several points need to be addressed now to cautiously move forward to prospective, randomized clinical trials.

\section{Is "Intuitive" Synonymous with "True" in Oncology?}

In principle, an immunomodulatory approach to cancer therapy does not at all guarantee clinical efficacy (55-57). Responsive tumor types, if detectable, must be distinguished from unaffected cancer forms. With respect to Coley's toxins the mesodermal embryonic origin is supposed to be a noteworthy predictive factor (58). However, the sensitivity can change with tumor progression. Acquisition of resistance to respond to changes in immune parameters, e.g. availability of cytokines, can happen in advanced stages of some cancer types (59). As often diligently documented, cytokines not only transmit tumorsuppressive signals. With respect especially to interleukin-1 and -6 , their growth-stimulatory action on several types of tumor cells should be taken into consideration (60-68). Similarly, the interactions between chemotherapeutic and immunomodulatory regimens can, at present, not be accurately predicted, urging patience for trials without unrealistically high expectations (69). It is at present unclear how responders can easily and unequivocally be recognized within studies. Production of various cytokines in vitro by activated monocytes or lymphocytes is suggested to be valuable for determination of the cellular immunity status of patients (70). Concerning treatment with interleukins, the initial number of MHC-expressing tumor cells or the stimulation index for the level of Creactive protein are recent suggestions for this purpose $(71,72)$. Other acute-phase proteins with potential impact on the performance of the host defence system like the complement-activating mannose-binding serum lectin may also be of importance. In order to be affected by cytokines like tumor necrosis factor- $\alpha$, tumor cells should express receptors, giving histochemical analysis of biopsy material potential value $(18,73)$. Viewing the NK-cell activity as a sound measure, interindividual differences, the various extents of sensitivity of the targets, and the influence of further factors such as stress should be noted $(74,75)$. The last factor clearly underscores the interrelationship of the neuroendocrine and immune systems $(76,77)$. Taking the popularity of the mistletoe treatment into account, the clinical setting should not neglect the potential for a placebo or a psychosocial effect, although care must be exercized concerning the measureable impact of such factors in oncology $(78,79)$.

Despite these cautionary remarks, the reviewed results may still nourish a serious misconception. Extract application, introduced and presently governed by intuition, is not scientifically justified. As clearly stated with respect to current expectations for therapy improvements by increased intensity of chemotherapy in conjunction with hematopoietic supportive care, not even the scientific use of the term "intuitive" is inevitably synonymous with "true" in oncology (80). Only well-designed, prospective studies provide the adequate arguments to distinguish wishful thinking or hypothesis from reality and facts.

\section{Acknowledgements}

We are indebted to Prof. J. Hölzl, Prof. G. Seitz, and Dr. A. W. L. Nose for critical reading of the manuscript. We gratefully acknowledge the outstanding secretarial assistance of A Krüger.

\section{References}

${ }^{1}$ Kaiser, G., Weiger, M., Gallmeier, W. M. (1992) Münch. Med. Wschr. 134, 774-778.

2 Lerner, I. J. (1984) Cancer 53, 815-819.

3 Berger, D. P., Obrist, R., Obrecht, J. P. (1989) Dtsch. Med. Wschr. 114, 323-330.

4 Morant, R., Jungi, W. F., Koehli, C., Senn, H. J. (1991) Schweiz. Med. Wschr. 121, 1029-1034.

5 Eisenberg, D. M., Kessler, R. C., Foster, C., Norlock, F. E., Calkins, D. R., Delbanco, T. L. (1993) N. Engl. J. Med. 328, 246-252.

${ }^{6}$ Hauser, S. P. (1991) Eur. J. Cancer 27, 1549-1551.

7 Hauser, S. P. (1993) Therapiewoche 43, 76-81.

8 Berger, M., Schmähl, D. (1983) J. Cancer Res. Clin. Oncol. 105, $262-265$

9 Bellmann, P. G., Daems, W. F. (1965) Sudhoffs Arch. 49, $355-363$.

10 Franz, H. (1985) Pharmazie 40, 97-104

11 Becker, H., Schmoll-Eisenwerth, H. (eds.) (1986) Mistel: Arzneipflanze, Brauchtum, Kunstmotiv im Jugendstil, Wissenschaftliche Verlagsgesellschaft, Stuttgart.

12 Schilcher, H. (1987) Schriftenreihe der Bundesapothekerkammer zur wissenschaftlichen Fortbildung XV, 69-93. 
${ }^{13}$ Pichler, W. J., Angeli, R. (1991) Dtsch. Med. Wschr. 116, $1333-1334$.

${ }^{14}$ Ziska, P., Franz, H. (1985) in: Lectins: Biology, Biochemistry, Clinical Biochemistry, Vol. IV, (Bog-Hansen, T. C., ed.), W. de Gruyter Verlag, Berlin, pp. 473-480.

15 Jordan, E., Wagner, H. (1986) Drug Res. 36, 428- 432.

${ }^{16}$ Gabius, H.-J. (1991) Biochim. Biophys. Acta 1071, 1-18.

17 Gabius, H.-J., Gabius, S. (eds.) (1991) Lectins and Cancer, Springer Verlag, Heidelberg.

${ }^{18}$ Gabius, S., Joshi, S. S., Kayser, K., Gabius, H.-J. (1992) Int. J. Oncol. 1, 705-708.

${ }^{19}$ Gabius, H.-J., Gabius, S. (eds.) (1993) Lectins and Glycobiology, Springer Verlag, Heidelberg.

${ }^{20}$ Luther, P., Theise, H., Chatterjee, B., Karduck, D., Uhlenbruck, G. (1980) Int. J. Biochem. 11, 429-435.

${ }^{21}$ Franz, H., Ziska, P., Kindt, A. (1981) Biochem. J. 195, $481-484$.

${ }^{22}$ Olsnes, S., Stirpe, F., Sandvig, K., Pihl, A. (1982) J. Biol. Chem. $257,13263-13270$.

${ }^{23}$ Endo, Y. (1989) Adv. Lectin Res. 2, 60-73.

24 Gabius. H.-J. (1990) Anal. Biochem. 189, 91-94.

${ }^{25}$ Gabius, H.-J., Walzel, H., Joshi, S. S., Kruip, J., Kojima, S., Gerke, V., Kratzin, H., Gabius, S. (1992) Anticancer Res. 12, $669-676$.

${ }^{26}$ Evensen, G., Mathiesen, A., Sundan, A. (1991) J. Biol. Chem. $266,6848-6852$.

${ }^{27}$ Schrader, G., Apel, K. (1991) Eur. J. Biochem. 198, 549- 553

28 Debray, H., Wieruszeski, J. M., Strecker, G., Franz, H. (1993) Carbohydr. Res., in press.

${ }^{29}$ Hegde, R., Podder, S. K. (1992) Eur. J. Biochem. 204, 155-164.

${ }^{30}$ Gabius, S., Kayser, K., Gabius, H.-J. (1991) Dtsch. Z. Onkol. 23, $113-119$.

31 Schink, M., Moser, D., Mechelke, F. (1992) Naturwissenschaften $79,80-81$.

32 Vang, O., Larsen, K. P., Bog-Hansen, T. C. (1986) in: Lectins: Biology, Biochemistry, Clinical Biochemistry, Vol. V, (BogHansen, T. C., van Driessche, E., eds.), W. de Gruyter Verlag, Berlin, pp. 637-644.

33 Lee, R. T., Gabius, H.-J., Lee, Y. C. (1992) J. Biol. Chem. 267, $23722-23727$

${ }^{34}$ Wu, A. M., Chin, L.-K., Franz, H., Pfüller, U., Herp, A. (1992) Biochim. Biophys. Acta 1117, 232-234.

${ }^{35}$ Bornens, M., Karsenti, E., Avrameas, S. (1976) Eur. J. Biochem. $65,61-69$

36 Prujansky, A., Ravid, A., Sharon, N. (1978) Biochim. Biophys. Acta 508, 137-146.

${ }^{37}$ Mann, P. L., Swartz, C. M., Holmes, D. T. (1988) Mech. Ageing Dev. 44, 1-16.

${ }^{38}$ Mann, P. L., Swartz, C. M., Holmes, D. T. (1988) Mech. Ageing Dev. $44,17-33$.

${ }^{39}$ Walzel, H., Bremer, H., Gabius, H.-J. (1993) in: Lectins and Glycobiology, (Gabius, H.-J., Gabius, S., eds.), Springer Verlag, Heidelberg, pp. 356-361.

${ }^{40}$ Hajto, T., Hostanska, K., Frei, K., Rordorf, C., Gabius, H.-J. (1990) Cancer Res. 50, 3322-3326.

${ }^{41}$ Schmidt, K. H. (1989) Planta Med. 55, 455- 457.

${ }^{42}$ Metzner, G., Franz, H., Kindt, A., Fahlbusch, B., Süss, J. (1985) Immunobiology $169,461-471$.

${ }^{43}$ Vester, F. (1977) Krebsgeschehen 9, 106-114.

44 Beuth, J., Ko, H. L., Gabius, H.-J., Pulverer, G. (1991) In vivo 5 , $29-32$

45 Joshi, S. S., Komanduri, K. C., Gabius, S., Gabius, H.-J. (1991) in: Lectins and Cancer, (Gabius, H.-J., Gabius, S., eds.), Springer Verlag, Heidelberg, pp. 207-216.

${ }^{46}$ Hajto, T., Hostanska, K., Gabius, H.-J. (1989) Cancer Res. 49, $4803-4808$

${ }^{47}$ Hajto, T., Hostanska, K., Gabius, H.-J. (1990) Therapeutikon 4, $136-145$.

${ }^{48}$ Klett, C. Y., Anderer, F. A. (1989) Drug Res. 39, 1580-1585.

${ }^{49}$ Mueller, E. A., Anderer, F. A. (1990) Cancer Immunol. Immunother. $32,221-227$.
${ }^{50}$ Beuth, J., Ko, H. L., Gabius, H.-J., Burrichter, H., Oette, K., Pulverer, G. (1992) Clin. Investig. 70, 658-661.

51 Beuth, J., Gabius, H.-J., Steuer, M. K., Geisel, J., Steuer, M., Ko, H. L., Pulverer, G. (1993) Med. Klinik 88, 287-290.

52 Koch, F. E. (1938) Z. ges. exp. Med. 103, 740-749.

53 Fodstad, O., Kvalheim, G., Godal, A., Lotsberg, J., Aamdal, S., Host, H., Pihl, A. (1984) Cancer Res. 44, 862-865.

${ }^{54}$ Stettin, A., Schultze, J. L., Stechemesser, E., Berg, P. A. (1990) Klin. Wschr. 68, 896-900.

55 Kaufmann, M. (1991) Curr. Opinion Oncol. 3, 1019-1023

${ }^{56}$ Hauschild, A., Sterry, W. (1992) Dtsch. Med. Wschr. 117, 303-306

57 Toi, M., Hattori, T., Akayi, M., Inokuchi, K., Orita, K., Sugimachi, K., Dohi, K., Nomura, Y., Monden, Y., Hamada, Y., Morimoto, T., Ogawa, N. (1992) Cancer 70, 2475-2483.

58 Starnes, C. O. (1992) Nature 357, 11-12.

59 Kerbel, R. S. (1992) Am. J. Pathol. 141, 519-524

${ }^{60}$ Bauer, J. (1989) Klin. Wschr. 67, 697-706

61 Cozzolino, F., Rubartelli, A., Aldinucci, D., Sitia, R., Torcia, M., Shaw, A., Di Guglielmo, R. (1989) Proc. Natl. Acad. Sci. USA 86, $2369-2373$

${ }^{62}$ Miki, S., Iwano, M., Miki, Y., Yamamoto, M., Tang, B., Yokokawa, K., Sonoda, T., Hirano, T., Kishimoto, T. (1989) FEBS Lett. 250, $607-610$.

${ }^{63}$ Scala, G., Quinto, I., Ruocco, M. R., Arcucci, A., Mallardo, M., Caretto, P., Forni, G., Venuta, S. (1990) J. Exp. Med. 172, 61-68.

64 Adams, E. F., Rafferty, B., White, M. C. (1991) Int. J. Cancer 49, $118-121$.

65 Bani, M. R., Garofalo, A., Scanziani, E., Giavazzi, R. (1991) J. Natl. Cancer Inst. 83,119-123.

66 Emilie, D., Coumbaras, J., Raphael, M., Devergne, O., Delecluse, H. J., Gisselbrecht, C., Michiels, J. F., Van Damme, J., Taga, T., Kishimoto, T., Crevon, M. C., Galanaud, P. (1992) Blood 80, $498-504$.

${ }^{67}$ Koo, A. S., Armstrong, C., Bochner, B., Shimabukuro, T., Tso, C.-L., de Kernion, J. B., Belldegrun, A. (1992) Cancer Immunol. Immunther. 35, 97-105.

${ }^{68}$ Lahm, H., Petral-Malec, D., Yilmaz-Ceyhan, A., Fischer, J. R., Lorenzoni, M., Givel, J.-C., Odartchenko, N. (1992) Eur. J. Cancer 28A, 1894-1899.

${ }^{69}$ Parmiami, G., Rivoltini, L. (1991) Curr. Opinion Oncol. 3, $1078-1086$

${ }^{70}$ Elsässer-Beile, U., von Kleist, S., Stähle, W., SchurhammerFuhrmann, C., Mönting, J. S., Gallati, H. (1993) Cancer 71, $231-236$

71 Broom, J., Heys, S. D., Whiting, P. H., Park, K. G. M., Strachan, A., Rothnie, I., Franks, C. R., Eremin, O. (1992) Br. J. Cancer 66, $1185-1187$

72 Eisenthal, A., Kashtan, H., Rabau, M., Ramakrishna, V., Chaitchik, S., Skornick, Y. (1993) Cancer Immunol. Immunother. 36, $101-107$.

73 Kayser, K., Gabius, S., Gabius, H.-J., Hagemeyer, O. (1992) Tumordiagn. Ther. 13, 190-195.

${ }^{74}$ Levy, S., Herberman, R., Lippman, M., d’Angelo, T. (1987) J. Clin. Oncol. 5, 348-353.

${ }^{75}$ Gudmundsdottir, I., Ögmundsdottir, H. M. (1992) APMIS 100, $737-746$

76 Blalock, J. E. (1985) Lymphokines 9, 1-13

77 Goetzl, E. J., Sreedharan, S. P. (1992) FASEB J. 6, 2646- 2652.

78 Lynöe, N. (1990) Scand. J. Soc. Med. 18, 149-153.

79 Gellert, G. A., Maxwell, R. M., Siegel, B. S. (1993) J. Clin. Oncol. 11, $66-69$

${ }^{80}$ Canellos, G. P., Demetri, G. D. (1993) J. Clin. Oncol. 11, 1- 2. 